\title{
Characterization of the Xanthomonas translucens Complex Using Draft Genomes, Comparative Genomics, Phylogenetic Analysis, and Diagnostic LAMP Assays
}

\author{
Paul A. Langlois, Jacob Snelling, John P. Hamilton, Claude Bragard, Ralf Koebnik, Valérie Verdier, Lindsay R. Triplett, \\ Jochen Blom, Ned A. Tisserat, and Jan E. Leach
}

First, second, sixth, seventh, ninth, and tenth authors: Department of Bioagricultural Sciences and Pest Management, Colorado State University, Fort Collins 80523-1177; second author: Department of Horticulture, Oregon State University, Corvallis 97331; third author: Department of Plant Biology, Michigan State University, East Lansing 48824; fourth author: Université catholique de Louvain, Earth and Life Institute, B1348 Louvain-la-Neuve, Belgium; fifth and sixth authors: IRD, CIRAD, University Montpellier, Interactions Plantes Microorganismes Environnement (IPME), 34394 Montpellier, France; seventh author: Department of Plant Pathology and Ecology, The Connecticut Agricultural Experiment Station, New Haven; and eighth author: Bioinformatics \& Systems Biology, Justus-Liebig-University Giessen, 35392 Giessen, Hesse, Germany.

Accepted for publication 10 January 2017.

\section{ABSTRACT}

Prevalence of Xanthomonas translucens, which causes cereal leaf streak (CLS) in cereal crops and bacterial wilt in forage and turfgrass species, has increased in many regions in recent years. Because the pathogen is seedborne in economically important cereals, it is a concern for international and interstate germplasm exchange and, thus, reliable and robust protocols for its detection in seed are needed. However, historical confusion surrounding the taxonomy within the species has complicated the development of accurate and reliable diagnostic tools for $X$. translucens. Therefore, we sequenced genomes of $15 \mathrm{X}$. translucens strains representing six different pathovars and compared them with additional publicly available $X$. translucens genome sequences to obtain a genome-based phylogeny for robust classification of this species. Our results reveal three main clusters: one consisting of pv. cerealis, one consisting of pvs. undulosa and translucens, and a third consisting of pvs. arrhenatheri, graminis, phlei, and poae. Based on genomic differences, diagnostic loop-mediated isothermal amplification (LAMP) primers were developed that clearly distinguish strains that cause disease on cereals, such as pvs. undulosa, translucens, hordei, and secalis, from strains that cause disease on noncereal hosts, such as pvs. arrhenatheri, cerealis, graminis, phlei, and poae. Additional LAMP assays were developed that selectively amplify strains belonging to pvs. cerealis and poae, distinguishing them from other pathovars. These primers will be instrumental in diagnostics when implementing quarantine regulations to limit further geographic spread of $X$. translucens pathovars.
The Xanthomonas translucens complex causes diseases on a broad host range of cereals and grasses. Classification of $X$. translucens pathovars has been based on the host from which they were first isolated or, sometimes, based on different symptoms caused on the same host or different hosts (Bragard et al. 1997; Vauterin et al. 2000). Diseases were assigned names for the different hosts infected or symptoms associated with the presence of $X$. translucens. When $X$. translucens infects the glumes of cereals, the disease is referred to as black chaff and, when infection results in blighting of cereal leaves, it is referred to as cereal leaf streak (CLS) (Dye et al. 1980). In forage or turf grasses, disease caused by $X$. translucens is referred to as bacterial wilt (Dernoeden et al. 2002; Egli and Schmidt 1982; Mitkowski et al. 2005).

Pathovar designation within $X$. translucens is also complicated because of overlapping host ranges among pathovars and variation in host ranges within pathovars (Maes et al. 1996). For example, CLS-associated strains, while often most virulent on the host of isolation (Rademaker et al. 2006), when inoculated also infect additional hosts, including bromegrass and quack grass (Azad and Schaad 1988; Boosalis 1952; Bragard et al. 1997; Rademaker et al.

Corresponding author: J. E. Leach; E-mail address: Jan.Leach@colostate.edu

P. A. Langlois and J. Snelling are co-first authors of this work.

*The $\boldsymbol{e}$-Xtra logo stands for "electronic extra" and indicates that three supplementary tables and three supplementary figures are published online.

(c) 2017 The American Phytopathological Society
2006). Some $X$. translucens strains colonize and cause disease on plants outside of the cereal and grass host range. For example, $X$. translucens pv. undulosa has been isolated from ornamental asparagus, and a newly proposed pathovar, X. translucens pv.pistachiae, isolated from pistachio orchards, is virulent on a number of hosts outside of its natural host range (Adhikari et al. 2012; Bull et al. 2012; Facelli et al. 2009; Marefat et al. 2006; Rademaker et al. 2006).

As a result of the above history, there are 10 named pathovars of $X$. translucens. Three pathovars are commonly isolated only from cereals (pvs. secalis, translucens, and undulosa), whereas pv. cerealis can be isolated from cereals and noncereals. For the purposes of this article, we define cereals as grasses that yield an edible grain grown for consumption (such as wheat, barley, rye, triticale, and so on) and noncereals as grasses that are grown for animal forage, found growing naturally, or for horticultural purposes (such as turfgrass or golf course fairway grasses). $X$. translucens pv. secalis is associated with rye and $X$. translucens pv. undulosa is found on wheat and triticale (Smith 2006). X. translucens pv. translucens includes strains from barley (Smith 2006), which were previously named pv. hordei but are considered pv. translucens (Bragard et al. 1997; Smith 2006). In addition to the three cereal pathovars, there are five $X$. translucens pathovars pathogenic to grasses (pvs. arrhenatheri, phlei, phleipratensis, poae, and graminis) (Maes et al. 1996). Finally, X. translucens pv. cerealis has been isolated from cereals and other grasses (e.g., Hordeum, Triticum, Bromus, and Lolium spp., and others) (Bragard et al. 1997; Rademaker et al. 2006).

A consequence of the overlapping host ranges is the complication of pathovar-level diagnosis for $X$. translucens. This is particularly 
important for the cereal pathovars, which are seed disseminated and, thus, subject to quarantine regulations (Majumder et al. 2013; Tubajika et al. 1998). Attempts to distinguish pathovars using DNADNA hybridization, membrane protein assays, and biochemical, physiological, and serological tests provided insights into variation within the species but did not resolve at the pathovar level (Azad and Schaad 1988; Bragard et al. 1995; Elrod and Braun 1947; Rademaker et al. 2006; Schaad 1979; Vauterin et al. 1990). Methods with improved resolving power, including genomic fingerprinting techniques such as amplified fragment length polymorphism and restriction fragment length polymorphism, did not allow a distinction at the pathovar level (Bragard et al. 1997; Maes et al. 1996; Rademaker et al. 2006; Vauterin et al. 2000). Of the methods in practice today for identification of $X$. translucens, the most commonly used include enrichment using semiselective media (Duveiller 1990; Schaad and Forster 1985), serological tests such as enzyme-linked immunosorbent assay (Duveiller et al. 1997; Frommel and Pazos 1994), immunofluorescence assays (Bragard et al. 1995; Duveiller and Bragard 1992), or ribosomal DNAbased polymerase chain reaction (PCR) amplification with primers to 16S, 23S, and internal transcribed spacer regions (Maes et al. 1996; Marefat et al. 2006; Mitkowski et al. 2005). Although these methods, particularly the PCR-based methods, have improved detection of $X$. translucens, they still do not differentiate among pathovars, nor do they reflect the relatedness within the $X$. translucens complex (Maes et al. 1996; Marefat et al. 2006; Mitkowski et al. 2005).

Although phytopathogenic specializations of Xanthomonas are frequently not correlated to phylogenetic relationships (Vauterin and Swings 1997), comparative genomic analyses have resolved relationships and distinctions among pathovars, geographical groups, or phylogenetic clades for some Xanthomonas spp. (Francis et al. 2013; Lang et al. 2014; Rasko et al. 2008; Triplett et al. 2014). Unique genomic regions identified in these analyses enabled development of pathovar-specific diagnostic tools, including PCRbased assays that distinguish $X$. arboricola pv. pruni from other $X$. arboricola pathovars (Pothier et al. 2011), X. oryzae pv. oryzae from X. oryzae pv. oryzicola (Lang et al. 2014), and X. oryzae pvs. oryzae and oryzicola from a U.S.-derived group of X. oryzae with no pathovar designation (Triplett et al. 2011).

For $X$. translucens, exploitation of comparative genomics information to clarify taxonomy and to develop pathovar-specific diagnostics has been limited by the small amount of genome sequence data available. The first three $X$. translucens draft genomes were made public in 2012: X. translucens DAR61454 (Gardiner et al. 2014), X. translucens pv. graminis ART-Xtg29 (Wichmann et al. 2013), and X. translucens pv. translucens DSM 18974 (CAPJ00000000). During the preparation of this article, draft genomes for $X$. translucens pv. cerealis CFBP2541 (Pesce et al. 2015b), X. translucens pv. graminis 2053 (Pesce et al. 2015a), and $X$. translucens pv. poae LMG728 (CXOK00000000), were announced, and the complete genome of X. translucens pv. undulosa strain XT4669 was determined through high-coverage PacBio and Illumina hybrid assemblies (Peng et al. 2016). These genome sequences are being used to better understand the pathogenic speializations and virulence mechanisms of this important Xanthomonas sp. (Peng et al. 2016; Pesce et al. 2015a, b; Wichmann et al. 2013).

In this study, we sequenced 15 genomes representing six different $X$. translucens pathovars. Our objectives were to use comparative genomic approaches to clarify the phylogenetic relationships among pathovars of $X$. translucens and to enable the development of robust diagnostic tools for related groups. Loop-mediated isothermal amplification (LAMP) assays were developed that distinguish $X$. translucens from other species of Xanthomonas and that distinguish $X$. translucens isolated from cereals from those isolated from noncereals.

\section{MATERIALS AND METHODS}

Genome sequencing and comparative genomics. Genomic DNA from $15 X$. translucens strains representing six pathovars were extracted using the Invitrogen, Easy-DNA gDNA Purification Kit, and sequenced using either the Illumina GAIIX or HiSeq2000 platforms for paired-end 75- or 100-bp reads, respectively. Sequencing was performed at the Research Technology Support Facility at Michigan State University, the Epigenome Center Data Production Facility at the University of Southern California, the Genome Center Core Facilities at the University of CaliforniaDavis, and DNA Vision in Belgium (Avenue George Lemaitre 25B-6041 Charleroi). Raw data were preprocessed prior to assembly using the FASTX toolkit (http://hannonlab.cshl.edu/fastx_toolkit/) for quality filtering, trimming, and sequencing adapter/linker removal. Sample-specific trimming was performed upon evaluation of base pair quality box plots, and median PHRED quality scores below Q20 were used as a threshold, typically resulting in the removal of 8 to $15 \mathrm{bp}$ from both sequence ends. Trimmed sequences were then filtered, requiring that $80 \%$ of bases in each read have quality scores $>$ Q20. Genomes were assembled with the Velvet short read sequence assembler, version 0.7 .53 or newer. Optimal parameters for $\mathrm{K}$, expected coverage, and coverage cutoff were determined using the VelvetOptimizer perl script (https://github. com/tseemann/VelvetOptimiser). Gene model predictions and annotations were machine annotated using the Rapid Annotation using Subsystem Technology (RAST) server (Aziz et al. 2008). Upon submission, draft genome assemblies were automatically reannotated using the National Center for Biotechnology Information (NCBI) Prokaryotic Genome Annotation Pipeline. Analyses dependent on predicted gene sequences in this article use the RAST-derived gene models. The RAST annotations are hosted at https://edgar.computational.bio.uni-giessen.de, and can be accessed by entering the EDGAR_X_translucens_ Phytopathology public project. Genome comparisons were made by virtual DNA-DNA hybridization of the assembled draft genome sequences by using JspeciesV1.2.1. Average nucleotide identity (ANI) values were determined by MUMmer (ANIm); ANI values greater than $95 \%$ are considered to correlate to DNA-DNA hybridization values that infer species boundaries (Goris et al. 2007). Draft genome assemblies, ANIm values, and publicly available $X$. translucens genomes were compared against the pathotype strains CFBP 2054 (pv. translucens), ATCC33804 (pv. poae), NCPPB1944 (pv. cerealis), and CFBP 2053 (pv. graminis). The open reading frames of 12 housekeeping genes (atpD, dnaK, fusA, fyaA, glnA, gltA, groEL, gyrB, kup, lepA, recA, and $r p o D$ ) were identified in the $X$. translucens genome assembled contigs. Sequences were concatenated and aligned, and gaps were removed using CLC Genomics Workbench, to yield $20 \mathrm{~kb}$ of sequence for multilocus sequence analysis (MLSA). The concatenated alignment was examined for the best-fit phylogenetic model using MEGA 6 (Kumar et al. 2008). Bayesian phylogenetic analyses were performed with the MrBayes program (Huelsenbeck and Ronquist 2001) using the general time-reversible model with inverse- $\gamma$ rates of evolution for $1,000,000$ generations. TreeGraph (http://treegraph.bioinfweb.info/) was used to construct a phylogenetic tree.

The EDGAR platform (Blom et al. 2009) was used to generate phylogenetic trees based on $42 X$. translucens strains, using the most closely related xanthomonad genome of $X$. albilineans GPE PC73 as an outlier. The core genome used in construction of the EDGAR tree consisted of 1,087 coding sequences (CDS) per genome, totaling 46,741 genes with 15,902,002 amino acid residues. EDGAR uses a straightforward bidirectional best-hits approach to define orthology, and only one-to-one orthologous pairs are used in the core genome calculation. The 1,087 core gene sets were aligned individually using the MUSCLE software (Edgar 2004) and subsequently concatenated. The resulting multiple alignment was used to generate a phylogenetic tree. A distance matrix was calculated using the Kimura method and a rooted tree was inferred using the unweighted pair group method with arithmetic mean (UPGMA) method as implemented in the PHYLIP package 
(Felsenstein 1995). The best-fit tree after 500 bootstrap replications was selected.

Primer design, optimization, and screening. To develop diagnostic primers that differentiate between the cereal and noncereal pathovars of $X$. translucens, unique sequences were identified using a genome alignment-based computational pipeline (designated Uniqprimer 0.5.0) (L. Triplett and J. E. Leach, unpublished data). The program identifies regions that are conserved among a group of target genomes (i.e., cereal pathovars) but distinct or absent from nontarget genomes (i.e., noncereal pathovars). Cereal- and pathovar-specific sequences output by the pipeline were entered in a BLAST search against all bacterial genome sequences in the NCBI Genome database to ensure that no close hits were obtained other than from cereal pathovars of $X$. translucens. Primers were then designed in these regions using the program Primer3 (http://bioinfo.ut.ee/primer3-0.4.0/), targeting an optimal annealing temperature of $60^{\circ} \mathrm{C}$ and product size range of 100 to $800 \mathrm{bp}$. The output list of primer pairs was mapped to the $X$. translucens cereal pathovar genomes using the Primersearch function in the EMBOSS package (Rice et al. 2000). Selected primer pairs confirmed to have perfect matches to the target $X$. translucens pathovars were advanced to PCR screening on a wider range of strains. Primers were synthesized by Integrated DNA Technologies (Coralville, IA).

Once specificity for the targeted regions was confirmed by conventional PCR, four LAMP-PCR primer sets were designed for each locus, each set consisting of a forward inner primer (FIP), a backward inner primer (BIP), a forward outer primer (F3), and a backward outer primer (B3), using Primer Explorer V4 (http:// primerexplorer.jp/e/). No loop primers were used. Specificity of LAMP primers was assessed first by screening target and nontarget bacterial isolates for amplification with the outer primers ( $\mathrm{F} 3$ and B3) with conventional PCR, followed by separation in agarose gels. One specific LAMP primer set was selected per locus for subsequent screening with other diverse bacteria. Once specificity was confirmed, the primers were tested for sensitivity of detection using serial dilutions of bacterial cells (below).

Bacterial isolates and plant samples. Bacterial DNA, bacterial cells, $X$. translucens-infected leaf tissue, and X. translucenscontaminated seed lots were used in LAMP detection assays. Bacterial DNA was purified using the Invitrogen Easy-DNA Kit, and was adjusted to $20 \mathrm{ng}^{-1} \mathrm{l}^{-1}$ for assays. For direct use in PCR assays, bacterial cells were streaked for single colonies from glycerol stocks onto nutrient agar and incubated at $28^{\circ} \mathrm{C}$ for 2 days. Bacteria were suspended in sterilized distilled water to an optical density at $600 \mathrm{~nm}\left(\mathrm{OD}_{600}\right)$ of 0.2 , and the suspensions were heated to $95^{\circ} \mathrm{C}$ for $15 \mathrm{~min}$ in a thermocycler prior to use as templates for PCR. X. translucens strains, seed lot samples, leaf samples, bacterial cultures received as unknowns, and all bacterial strains used in this study are listed in Supplementary Tables S1 and S2. Purified bacterial isolates were stored long term in $25 \%$ glycerol at $-80^{\circ} \mathrm{C}$.

Seed lot and leaf samples were tested for presence of $X$. translucens by culture methods as well as LAMP assays. To isolate bacteria from leaf tissue exhibiting disease symptoms, approximately $3 \mathrm{~mm}^{2}$ of wheat or barley leaf tissue, including the edge of necrotic lesions, was excised. Leaf tissue pieces were soaked in $1 \mathrm{ml}$ of distilled water for $5 \mathrm{~min}$ and crushed with a pipette tip. A $100-\mu \mathrm{l}$ aliquot of each extract was treated at $95^{\circ} \mathrm{C}$ for $15 \mathrm{~min}$ and used as template for PCR and LAMP reactions. The remaining extracts were diluted serially to $10^{-4}$ or $10^{-5}$, and $100 \mu \mathrm{l}$ of each dilution was spread on modified Wilbrink's boric acid-cephalexin (WBC) semiselective medium containing cephalexin at $10 \mathrm{mg} \mathrm{liter}^{-1}$, neomycin at $5 \mathrm{mg}$ liter-1, and cycloheximide at $200 \mathrm{mg} \mathrm{liter-1}^{-1}$ (Duveiller 1990; Spradlin 1990).

Bacterial isolation from contaminated barley seed lots was performed using a seed-washing procedure (Schaad and Donaldson 1980), in which samples of $40 \mathrm{~g}$ of seed were mixed with $40 \mathrm{ml}$ $(\mathrm{wt} / \mathrm{vol}=1: 1)$ of cold saline solution $(0.85 \% \mathrm{NaCl}$ containing
$0.02 \%$ [vol/vol] Tween 20) and shaken vigorously for 3 to $5 \mathrm{~min}$. After settling for $1 \mathrm{~min}, 100 \mu \mathrm{l}$ of supernatant was heat treated at $95^{\circ} \mathrm{C}$ for $15 \mathrm{~min}$ in a thermocycler, and then used as template for LAMP reactions to detect $X$. translucens. Of the remaining supernatant, $1 \mathrm{ml}$ was serially diluted to $10^{-4}$ or $10^{-5}$, and $100 \mu \mathrm{l}$ was spread evenly across three plates of modified WBC media. Suspected $X$. translucens colonies appearing on modified WBC were subcultured for further testing by LAMP-PCR.

Reaction conditions and mixtures for LAMP. Real-time LAMP reactions were performed on a Bio-Rad CFX Connect RealTime (Bio-Rad, Hercules, CA) system at $65^{\circ} \mathrm{C}$. The reaction mixture contained $7.2 \mu \mathrm{l}$ of Isothermal Master Mix (Optigene, Sussex, United Kingdom), $640 \mathrm{nM}$ FIP/BIP, and $64 \mathrm{nM} \mathrm{F3/B3}$ for ina-Xt, gyrB-Xt, and Xt-CLS primers, respectively. The Xt-Poae and the Xt-Cerealis primers were added at half the concentrations

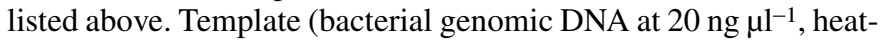
killed bacterial cells, seed wash supernatant, or excised leaf tissue extract) was added at $1 \mu \mathrm{l}$ per $12-\mu \mathrm{l}$ reaction and incubated in a real time thermal cycler. Samples were incubated for $70 \mathrm{~min}$ at $65^{\circ} \mathrm{C}$ for isothermal amplification followed by a melt curve analysis from 60 to $95^{\circ} \mathrm{C}$ in $0.5^{\circ} \mathrm{C}$ increments to observe LAMP product melt temperature ranges. Consistent melt temperature ranges indicated amplification of the same single region and demonstrated target specificities. All LAMP assays were replicated at least twice per sample, and all experiments included positive controls (DNA from known strains) and no-template controls.

We tested visual detection protocols for LAMP-PCR assays to facilitate field diagnosis. Visual detection LAMP assays were performed by heating the reaction mixture in a thermal cycler or a water bath at $65^{\circ} \mathrm{C}$ for $70 \mathrm{~min}$. The $25-\mu \mathrm{l}$ reaction mixtures were as follows: 0.8 M Betaine (B0300-1VL; Sigma-Aldrich, St. Louis), $1.4 \mathrm{mM}$ dNTP, $6 \mathrm{mM}$ additional $\mathrm{MgSO}_{4}$ for a final concentration of $8 \mathrm{mM}$ (New England Biolabs, Ipswich, MA), 10× Isothermal Amplification Buffer (B0537S; New England Biolabs), the respective LAMP primers at the concentrations mentioned above, $4 \mathrm{U}$ of Bst DNA Polymerase 2.0 (New England Biolabs), and $2 \mu \mathrm{l}$ of template. Mineral Oil (EMD Millipore, Darmstadt, Germany) was added on top of the reaction mixture $(20 \mu \mathrm{l})$ to minimize introduction of aerosolized product in workspaces. Reactions were performed in individual $0.2-\mathrm{ml}$ PCR tubes to prevent cross contamination during pipetting. To prevent the release of aerosols, we used a closed tube system in which $2 \mu \mathrm{l}$ of a 1:1 mix of Quant-IT PicoGreen Reagent (P11495; Invitrogen, Carlsbad, CA) and glycerol was added to the inside of reaction tube lids. After completion of reactions, the tubes were centrifuged briefly, vortexed, and examined under normal and ultraviolet light to determine amplification.

LAMP primer specificities were determined using a pooling strategy to screen collections of bacterial species (Lang et al. 2014). Nontarget bacterial DNA (40 ng each) or dead bacterial cells adjusted to an $\mathrm{OD}_{600}$ of $0.2(2 \mu \mathrm{l}$ each) were pooled in equal concentrations of 10 different isolates in each pool. A duplicate of each pooled sample was spiked with $1 \mu$ of positive-control genomic DNA or $X$. translucens cells to validate detection in a mixed sample. $X$. translucens strains from diverse geographic regions and different hosts were screened individually using the ina$\mathrm{Xt}$ and $g y r B$-Xt primers, as well as the pathovar-specific primers $\mathrm{Xt}$-Poae and Xt-Cerealis and the cereal-specific Xt-CLS primers. Positive controls included known $X$. translucens strains whose genomes were used in primer design and others that had been tested previously via pathogenicity tests and confirmed to be $X$.translucens. All bacterial strains and pooled bacterial samples were screened a minimum of two times with each assay. Assay sensitivities were determined using serial dilutions (1:10) of heat-killed cells adjusted to an $\mathrm{OD}_{600}$ of 0.2 (approximately $1 \times 10^{8} \mathrm{CFU} \mathrm{ml}^{-1}$ ). Each dilution (from $10^{8}$ to $10^{1} \mathrm{CFU} \mathrm{ml}{ }^{-1}$ ) was tested a minimum of three times and averaged, and standard deviations were calculated to correlate bacterial number with cycle of amplification. 


\section{RESULTS}

Draft genome sequence and assembly. Assembly details for the 15 draft genome sequences generated for $X$. translucens strains representing six pathovars are shown in Table 1. Assemblies ranged between 4.21 and $4.96 \mathrm{Mb}$, with guanine-cytosine content of 65.6 to $68 \%$. The draft genome sequence data of the strains from this study are deposited into NCBI and are under the accessions LWSU00000000, LWSV00000000, LWSW00000000, LWSX00000000, MADM00000000, MADN00000000, MADO00000000, MADP00000000, MADQ00000000, MADR00000000, MADS00000000, MADT00000000, MADU00000000, and MADV00000000, with JTEM00000000 being deposited in 2014. The raw sequence reads are deposited in the NCBI sequence read archive.

Comparative genomics and phylogeny. To examine relationships among the species, we compared assembled $X$. translucens genomic contigs, including those we generated and the publicly available genomes, in a pairwise manner using JSpecies and MUMer. All individual comparisons examined within the species complex fell at or above the accepted 95\% ANIm threshold value for species delineation (Table 1; Supplementary Table S3).

MLSA was used for preliminary examination of phylogenetic relationships among six representative $X$. translucens pathovars (21 strains). Twelve housekeeping genes—atpD (1,280 bp), dnaK (1,908 bp), fusA (2,006 bp), fyaA (2,135 bp), glnA (1,396 bp), gltA (1,046 bp), groEL (1,586 bp), gyrB (2,344 bp), kup (1,807 bp), lepA ( $1,783 \mathrm{bp})$, recA (999 bp), and $r p o D(1,810 \mathrm{bp})$ —were included in a concatenated set of $20 \mathrm{~kb}$. Using the best-fit phylogenetic model in MEGA 6, a maximum-likelihood tree was constructed from the MLSA data (Fig. 1). The phylogenetic reconstruction distinguished cereal and noncereal $X$. translucens pathovars into two distinct clades. The noncereal isolates grouped into smaller subclades, in general reflecting their pathovar designation. Within the cereal clade, pv. cerealis strains formed a subclade that was distinct from the larger grouping of cereal pathogens (including pv. translucens and undulosa strains).

Using additional $X$. translucens genomes recently added to the public domain, we further addressed the relationships within the $X$. translucens complex by contrasting pathovar-specific core genomes and their associated homologous protein CDS using EDGAR (Blom et al. 2009, 2016). A phylogenetic tree generated from the analysis of 1,087 orthologous CDS, shared among $42 X$. translucens genomes and the most closely related xanthomonad genome, $X$. albilineans, resulted in groupings very similar to those observed in the MLSA analysis but with an increase in subclade resolution (Supplementary Fig. S1). Major clade groupings observed on the UPGMA tree corresponded to ANIm values of 97 to $98 \%$, with subclade values corresponding to ANIm values $>98.5 \%$ for the data set. A Venn diagram (Fig. 2) was constructed using EDGAR that is based on pathovar-specific core genome groupings, determined from the tree's most visibly distinct subclades. EDGAR allows for a maximum of five comparisons for Venn diagram interpretation; thus, we included the core genomes of pv. cerealis (2,707 CDS), subclade-specific pv. poae (3,491 CDS), subclade-specific pvs. graminis, arrhenatheri, phlei, and poae $(2,547$ CDS), pvs. undulosa and translucens (2,230 CDS), and subcladespecific pv. translucens (2,464 CDS) in the comparison. The resulting Venn diagram, representing all 42 strains, shows a core genome of 1,392 highly orthologous genes in the $X$. translucens species complex. The variable genome includes tens to hundreds of unique orthologous genes per pathovar-specific core genome. Unique singletons, gene duplications, and paralogs are not included in the analysis but would contribute additional hundreds to thousands of unique adaptations within each subclade and individual genome.

LAMP assay sensitivities and specificities. Using genomic regions that were unique to (i) the species $X$. translucens relative to other Xanthomonas spp., (ii) pv. cerealis, (iii) pv. poae, and (iv) and

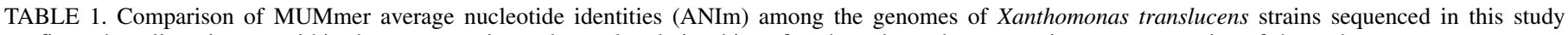
confirms that all strains are within the same species and reveals relationships of each to the pathotype strain or representative of the pathovar

\begin{tabular}{|c|c|c|c|c|c|c|c|c|c|}
\hline \multirow[b]{2}{*}{$\begin{array}{l}\text { Pathovar } \\
\text { (accession number) }\end{array}$} & \multirow[b]{2}{*}{ Strain $^{v}$} & \multirow[b]{2}{*}{$\mathrm{SL}(\mathrm{Mb})^{\mathrm{w}}$} & \multirow[b]{2}{*}{$\operatorname{CDS}^{x}$} & \multirow[b]{2}{*}{$\mathrm{GC}(\%)^{\mathrm{y}}$} & \multicolumn{5}{|c|}{ ANIm } \\
\hline & & & & & $\begin{array}{c}\text { CFBP } 2054 \\
\text { (pv. translucens) }\end{array}$ & $\begin{array}{l}\text { ATCC-33804 } \\
\text { (pv. poae) }\end{array}$ & $\begin{array}{l}\text { NCPPB } 1944 \\
\text { (pv. cerealis) }\end{array}$ & $\begin{array}{l}\text { CFBP } 2053 \\
\text { (pv. graminis) }\end{array}$ & Source \\
\hline arrhenatheri (LWSX00000000) & UPB455 & 4.76 & 3845 & 68.3 & 95.7 & 96.5 & 95.1 & 97.7 & $\begin{array}{l}\text { Arrhenatherum elatius: } \\
\text { Switzerland }\end{array}$ \\
\hline cerealis (MADM00000000) & $\begin{array}{c}\text { NCPPB1943/ } \\
\text { LMG7393 }\end{array}$ & 4.42 & 3730 & 67.4 & 95.1 & 95.0 & 99.8 & 95.1 & $\begin{array}{l}\text { Hordeum vulgare: United } \\
\text { States }\end{array}$ \\
\hline graminis (LWSW00000000) & UPB437 & 4.21 & 3495 & 68.6 & 95.8 & 96.5 & 95.0 & 99.9 & $\begin{array}{l}\text { Lolium multiflorum: } \\
\text { Switzerland }\end{array}$ \\
\hline poae (MADN00000000) & $\begin{array}{c}\text { ATCC-33804 } / \\
{\text { LMG } 728^{\mathrm{r}} /}^{\text {CFBP } 2057^{\mathrm{T}}}\end{array}$ & 4.52 & 3892 & 67.8 & 95.6 & $\ldots$ & 95.0 & 96.6 & Poa trivialis: Switzerland \\
\hline poae (MADO00000000) & CNC2-P4 & 4.59 & 3870 & 67.9 & 95.6 & 99.9 & 95.0 & 96.5 & Turfgrass: North Carolina \\
\hline poae (MADP00000000) & Utah5-P1 & 4.61 & 3954 & 68.1 & 95.8 & 96.5 & 95.1 & 97.5 & Turfgrass: Utah \\
\hline poae (LWSU00000000) & B99 & 4.57 & 3760 & 68.1 & 95.5 & 99.8 & 94.9 & 96.5 & Turfgrass: Illinois \\
\hline translucens (MADQ00000000) & SIMT-07 & 4.53 & 3986 & 67.9 & 97.5 & 95.5 & 95.2 & 95.7 & H. vulgare: Montana \\
\hline translucens (MADR00000000) & SLV-2 & 4.6 & & 66.2 & 97.7 & 95.6 & 95.3 & 95.8 & H. vulgare: Colorado \\
\hline translucens (MADS00000000) & BLSB3 & 4.56 & 4068 & 67.6 & 97.6 & 95.5 & 95.3 & 95.7 & H. vulgare: North Dakota \\
\hline translucens (LWSV00000000) & $\begin{array}{l}\text { UPB458/ } \\
\text { NCPPB2389 }\end{array}$ & 4.52 & 3900 & 67.8 & 98.5 & 95.4 & 94.8 & 95.5 & H. vulgare: India \\
\hline translucens (JTEM00000000) & $\mathrm{UPB} 787^{\mathrm{a}}$ & 4.54 & 3899 & 67.8 & 98.8 & 95.7 & 95.2 & 96.0 & H. vulgare: Paraguay \\
\hline undulosa (MADT00000000) & NARK-1 & 4.49 & 3809 & 68.0 & 97.6 & 95.5 & 95.2 & 95.7 & $\begin{array}{l}\text { Triticum aestivum: } \\
\quad \text { Arkansas }\end{array}$ \\
\hline undulosa (MADU00000000) & BLSW16 & 4.6 & 4112 & 67.5 & 97.5 & 95.5 & 95.2 & 95.7 & T. aestivum: North Dakota \\
\hline undulosa (MADV00000000) & UPB513 & 4.48 & 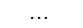 & 67.9 & 97.6 & 95.5 & 95.2 & 95.7 & T. aestivum: Mexico \\
\hline $\begin{array}{l}\text { Previous }^{\mathrm{z}} \\
\text { cerealis } \text { (JWHD01000000) }\end{array}$ & $\begin{array}{l}\text { NCPPB1944/ } \\
\text { UPB945/ } \\
\text { CFBP 2541 }\end{array}$ & 4.5 & 3771 & 67.3 & 95.1 & 95.0 & $\cdots$ & 95.0 & $\begin{array}{l}\text { Bromus inermis: United } \\
\text { States }\end{array}$ \\
\hline graminis (LHSI00000000) & $\begin{array}{l}\text { UPB1156/ } \\
\text { CFBP2053 }\end{array}$ & 4.34 & 3761 & 68.3 & 95.7 & 96.5 & 95.0 & $\cdots$ & $\begin{array}{l}\text { Dactylis glomerata: } \\
\text { Switzerland }\end{array}$ \\
\hline graminis (ANGG00000000) & ART-Xtg29 & 4.1 & 3587 & 68.6 & 95.8 & 96.5 & 95.1 & 99.9 & $\begin{array}{l}\text { L. multiflorum: } \\
\text { Switzerland }\end{array}$ \\
\hline translucens (AMXY01000000) & DAR61454 & 4.47 & 3759 & 68.1 & 97.5 & 95.5 & 95.2 & 95.6 & T. aestivum: Australia \\
\hline translucens (CAPJ01000155) & $\begin{array}{r}\text { DSM18974 T/ } \\
\text { CFBP } 2054\end{array}$ & 4.46 & 3897 & 67.7 & $\ldots$ & 95.6 & 95.1 & 95.8 & H. vulgare: Minnesota \\
\hline undulosa (СР008714) & Xtu $4669^{\mathrm{g}}$ & 4.56 & 3783 & 68.1 & 97.5 & 95.5 & 95.2 & 95.6 & Triticum spp.: Kansas \\
\hline
\end{tabular}

${ }^{\mathrm{v}}$ Superscripts: ${ }^{\mathrm{T}}=$ pathoype strain, ${ }^{\mathrm{a}}=$ genome also from this study but announced previously, $\mathrm{g}=$ reference genome, and ${ }^{\mathrm{r}}=$ pathovar reference strain .

w Sequence length.

x Coding sequences.

y Guanine-cytosine.

z Previously published or announced genomes (accession number). 


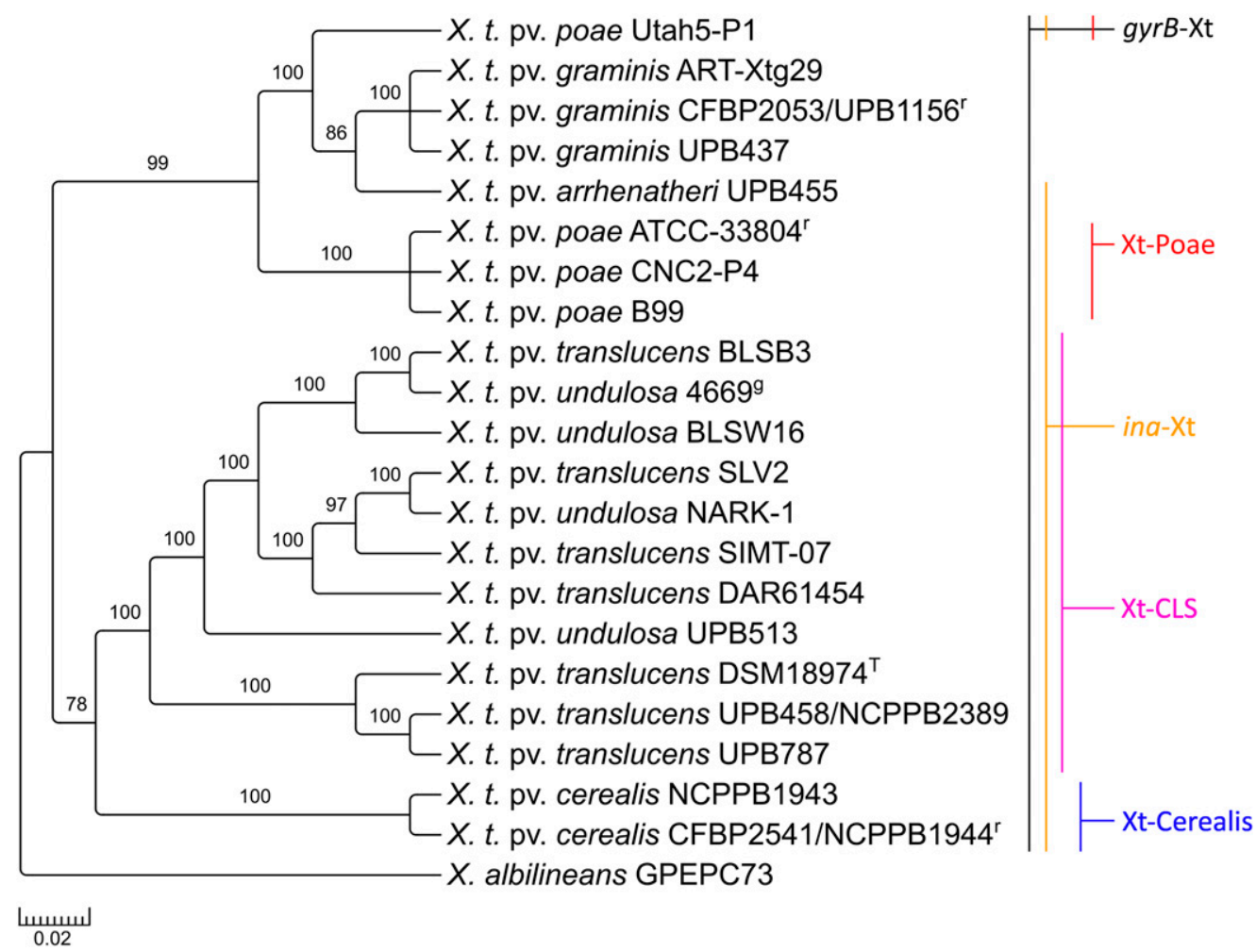

Fig. 1. Phylogenetic tree of Xanthomonas translucens pathovars (21 strains) based on $20 \mathrm{~kb}$ of concatenated sequences of 12 housekeeping genes (atpD, dnaK, fusA, fyaA, glnA, gltA, groEL, gyrB, kup, lepA, recA, and rpoD) that were identified from available $X$. translucens genome assembled contigs. Using the best-fit phylogenetic model in MEGA 6, X. translucens pathovars are distinguished into three clades by multilocus sequence analysis: cereals, noncereals, and pv. cerealis. Bayesian phylogenetic analyses were performed using the MrBayes program, using the general time-reversible model with inverse- $\gamma$ rates of evolution for $1,000,000$ generations. The phylogenetic tree was constructed using TreeGraph 2. X. albilineans was included as an outgroup. Primer assays from this study that amplify or are expected to amplify the strains in the tree are shown to the right. Each shaded vertical line represents one primer set.

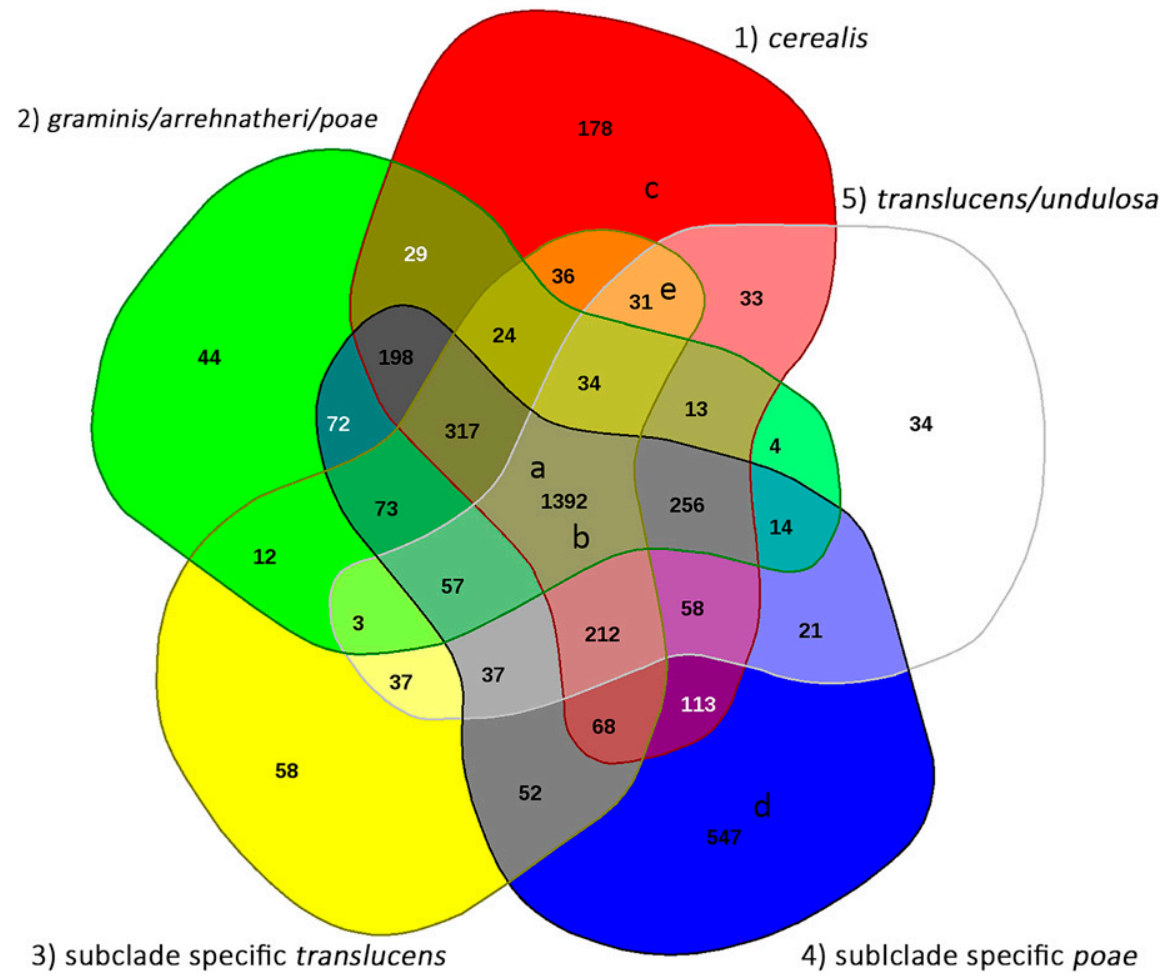

Fig. 2. Venn diagram constructed using EDGAR that is based on pathovar-specific core genome groupings and shows unique and shared homologous protein coding sequences among five different Xanthomonas translucens pathovar core genomes, representing 42 strains. Core genome groupings represent Xanthomonas translucens pvs. 1) cerealis; 2) graminis, arrhenatheri, poae, and phlei; 3) subclade-specific translucens; 4) subclade-specific poae; and 5) translucens and undulosa. Sequences to primers that amplify within indicated sectors are designated as lowercase letters: $\mathrm{a}=$ ina-Xt, $\mathrm{b}=$ gyrB-Xt, $\mathrm{c}=\mathrm{Xt}-\mathrm{Cerealis}, \mathrm{d}=\mathrm{Xt}-\mathrm{Poae}$, and $\mathrm{e}=\mathrm{Xt}-\mathrm{CLS}$. 
the group of pvs. translucens, hordei, undulosa, and secalis, we designed five sets of LAMP primers (Table 2). Alignment of the primers to draft genome sequences confirmed specificity for amplification of each of the targets (Supplementary Fig. S2). The primers and LAMP assays were tested on 8 other bacterial genera and 15 other species and pathovars of Xanthomonas, for a total of over 150 bacteria from 18 countries. All primers amplified only their intended targets (Table 3). All five sets of LAMP primers detected their targets in dilutions of heat-killed bacteria over the range of $10^{3}$ to $10^{4} \mathrm{CFU} \mathrm{ml} \mathrm{m}^{-1}$ when assays were performed in a realtime thermal cycler (Figs. 3 and 4). Assay sensitivity thresholds were consistent with previous reports for other plant-pathogenic bacteria, ranging from $10^{3}$ to $10^{4} \mathrm{CFU} \mathrm{ml}^{-1}$ (Ash et al. 2014; Bühlmann et al. 2013; Lang et al. 2014). The gyrB-Xt primers amplified all $X$. translucens pathovars. The ina-Xt primer set, developed from the conserved ice nucleation gene inaX, did not amplify $X$. translucens pv. graminis strains or the single $X$. translucens pv. phlei strain tested but did amplify all strains in the remaining eight $X$. translucens pathovars. LAMP assays using the Xt-Cerealis, Xt-Poae, and Xt-CLS primers amplified only their target pathovars (Table 3).
We tested visual detection protocols for LAMP-PCR assays to facilitate field diagnoses. Reactions included PicoGreen, and were performed in individual $0.2-\mathrm{ml}$ tubes in both thermal cyclers and laboratory water baths for $70 \mathrm{~min}$ at $65^{\circ} \mathrm{C}$. For all primer sets, specific targets were amplified and detected from heat-killed bacterial cells and crude preparations from barley seed or wheat and barley leaf tissue. An example showing detection of PicoGreenstained products using the Xt-Poae LAMP assay is shown in Supplementary Figure S3.

Detection from leaf and seed field samples. Barley leaves and seed lots and wheat leaves that exhibited varying degrees of symptoms, and that were suspected of being infected with $X$. translucens, were tested for the presence of $X$. translucens using the LAMP-PCR assays (Table 4). Of the 13 barley seed lots, all but 2 were positive in LAMP assays for $X$. translucens, and only the 2 that were negative for amplification did not yield $X$. translucens-like colonies on modified WBC media. The isolates did not amplify with the Xt-Cerealis or Xt-Poae primers but did amplify with the Xt-CLS primers. Similarly, the four barley leaf samples that were symptomatic for CLS yielded $X$. translucens-like colonies on modified WBC media, and amplified with the ina-Xt, gyrB-Xt, and

TABLE 2. Sequences of loop-mediated isothermal amplification primers that amplify Xanthomonas translucens pathovars

\begin{tabular}{|c|c|c|c|}
\hline Primers $^{\mathrm{z}}$ & Nucleotide sequence & X. translucens targets & Gene \\
\hline FIP & 5'-TATCGTAGCCGGCGGTCTGGGACGGCGGGTCACGACA-3' & $\begin{array}{l}\text { All pathovars except } \\
\text { graminis }\end{array}$ & Ice nucleation protein \\
\hline F3 & 5'-GGCTACGGCAGTACCTCG-3' & $\ldots$ & $\ldots$ \\
\hline B3 & 5'-GCCAGCGGTCTGCGTA-3' & $\ldots$ & $\ldots$ \\
\hline \multicolumn{4}{|l|}{ gyrB-Xt } \\
\hline B3 & 5'-CTGCCGGTGGACGAGT-3' & $\ldots$ & $\ldots$ \\
\hline \multicolumn{4}{|l|}{ Xt-CLS } \\
\hline FIP & 5'-AGCCAGATTGGCTTGCCTGCGATGAGGTGGCGCATTGG-3' & $\begin{array}{l}\text { pvs. undulosa, translucens } \\
\text { (hordei), secalis }\end{array}$ & Hypothetical protein \\
\hline BIP & 5'-TGCAAGACAAATCTTCGTGCGCGTAGACAACTGCGCTTCCG-3' & $\ldots$ & $\cdots$ \\
\hline F3 & 5'-AACGAGCGAAGCCGTATG-3' & $\ldots$ & $\ldots$ \\
\hline B3 & 5'-CTCTTGGGTGTGCGGAAG-3' & $\ldots$ & $\ldots$ \\
\hline Xt-Cerealis & & $\ldots$ & $\ldots$ \\
\hline FIP & 5'-TAGATCGCTTCTGCTTCGGCTGTTTACGTCGAATCGTTCCGG-3' & pv. cerealis & $\begin{array}{l}\text { Spans the EF hand domain/calcium } \\
\text { binding protein and pteridine- } \\
\text { dependent deoxygenase }\end{array}$ \\
\hline BIP & 5'-CTATCAGTTCGTGCGCTCGCCCTACTGGACGGTCGTGTCT-3' & $\ldots$ & \\
\hline F3 & 5'-GGCAAGCCGAACCAAAGT-3' & $\ldots$ & $\ldots$ \\
\hline B3 & 5'-CGTTGAATAGCGACTGCGG-3' & $\ldots$ & $\ldots$ \\
\hline
\end{tabular}

${ }^{\mathrm{z}}$ Primer sets and single primers. Primers were designed using PrimerExplorer V4 software based on unique genomic regions found by genome comparisons. $\mathrm{FIP}=$ forward inner primer, BIP = backward inner primer, $\mathrm{F} 3$ = forward outer primer, and B3 = backward outer primer.

TABLE 3. Summary showing the specificity of Xanthomonas translucens primers in loop-mediated isothermal amplification assays

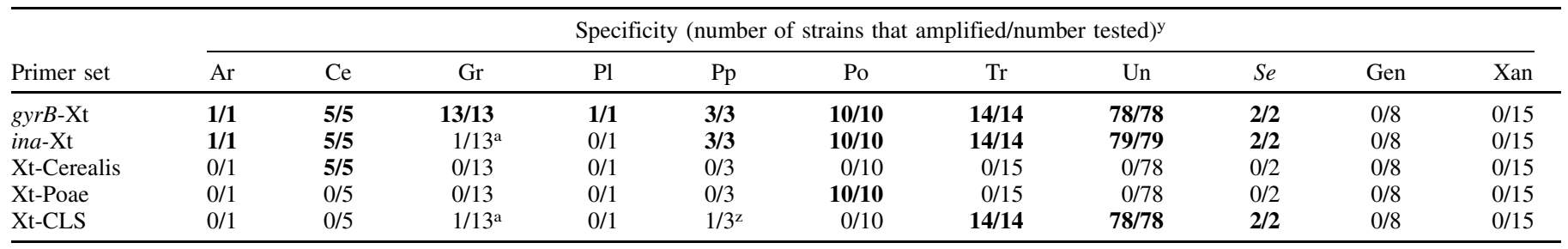

${ }_{\mathrm{y}}$ Abbreviations: $\mathrm{Ar}=$ pv. arrhenatheri, $\mathrm{Ce}=$ pv. cerealis, $\mathrm{Gr}=\mathrm{pv}$. graminis, $\mathrm{Pl}=\mathrm{pv}$. phlei, $\mathrm{Pp}=$ pv. phleipratensis, $\mathrm{Po}=\mathrm{pv}$. poae, $\mathrm{Tr} .=\mathrm{pv}$. translucens, Un $=$ pv. undulosa, $\mathrm{Se}=$ pv. secalis, Gen = other genera, and Xan = other Xanthomonas spp. Data in bold = expected to amplify with the primer set in the same row.

${ }^{\mathrm{z}}$ Uncertain historical classification of $X$. translucens pv. graminis UPB437 and pv. phleipratensis UPB441. 


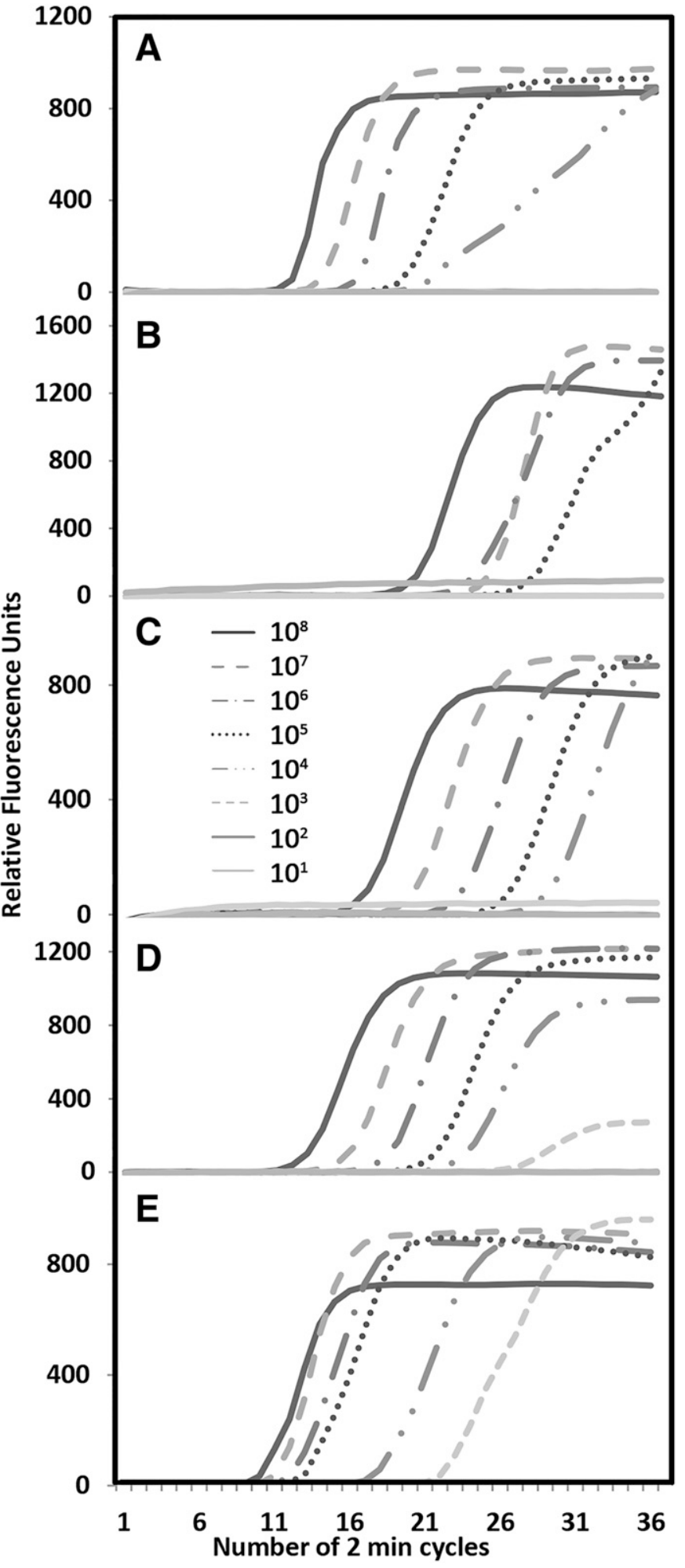

Fig. 3. Sensitivity of real-time thermal cycler loop-mediated isothermal amplification primers using dilutions of Xanthomonas translucens heat-killed cells. A, ina-Xt, amplifies $X$. translucens pathovars excluding pv. graminis, showing amplification using barley-seed-isolated $X$. translucens pv. translucens (from Merit 57 barley) heat-killed cells; B, gyrB-Xt, amplifies all $X$. translucens pathovars, showing amplification using barley-seed-isolated $X$. translucens pv. translucens (from Merit 57 barley) heat-killed cells; C, $X$. translucens pv. cerealis-specific Xt-Cerealis, showing amplification of $X$. translucens pv. cerealis B50 heat-killed cells; $\mathbf{D}, X$. translucens pv. poaespecific Xt-Poae, showing amplification of $X$. translucens pv. poae ATCC33804 heat-killed cells; and E, X. translucens cereal leaf streak-specific Xt-CLS, showing amplification using barley-seed-isolated X. translucens pv. translucens (from Merit 57 barley) heat-killed cells. Each template and each dilution were tested three times.

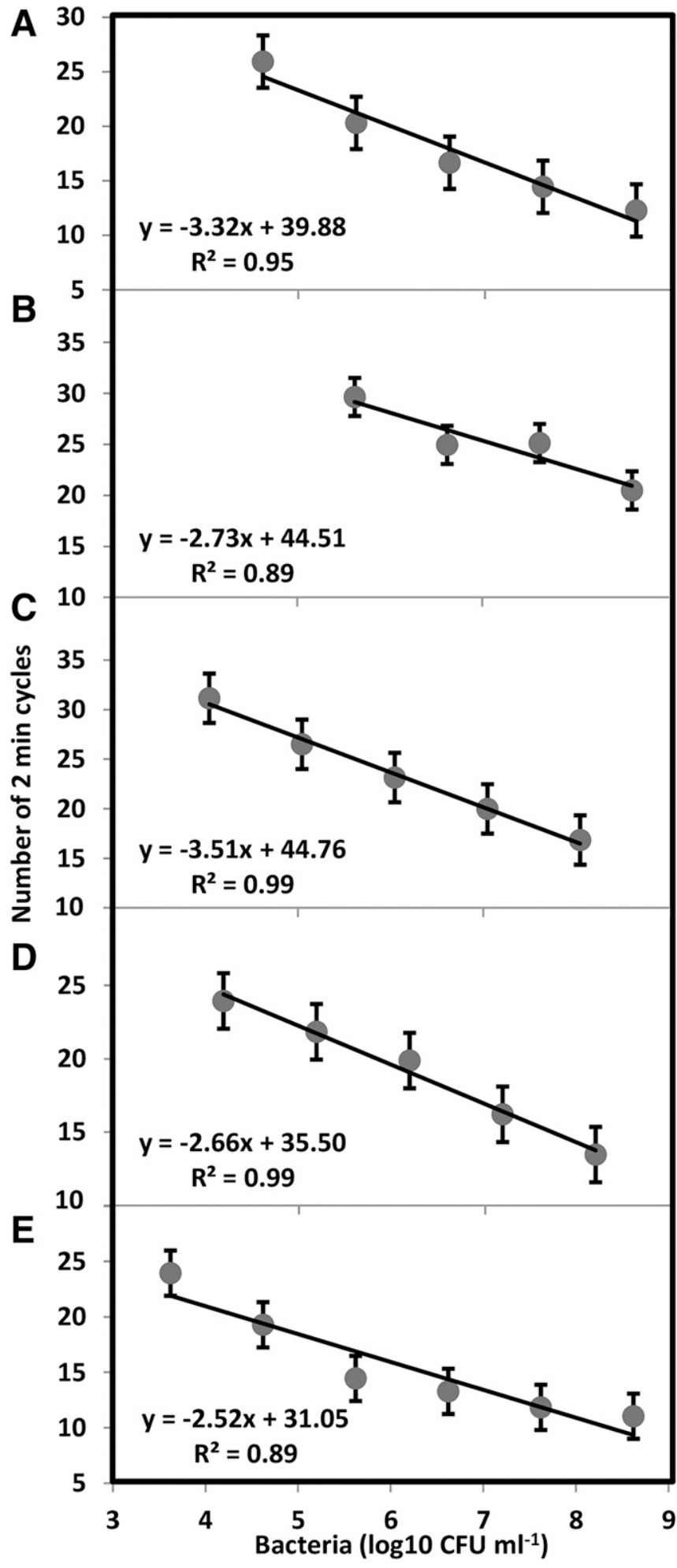

Fig. 4. Standard curves showing the sensitivity of detection of loop-mediated isothermal amplification primers using dilutions of Xanthomonas translucens heat-killed cells. A, ina-Xt, amplifies Xanthomonas translucens pathovars excluding pv. graminis, showing amplification using barley-seed-isolated $X$. translucens pv. translucens (from Merit 57 barley) heat-killed cells; B, gyrB-Xt, amplifies all $X$. translucens pathovars, showing amplification using barley-seedisolated $X$. translucens pv. translucens (from Merit 57 barley) heat-killed cells; C, X. translucens pv. cerealis-specific Xt-Cerealis, showing amplification of $X$. translucens pv. cerealis B50 heat-killed cells; D, X. translucens pv. poae-specific Xt-Poae, showing amplification of $X$. translucens pv. poae ATCC33804 heat-killed cells; and E, X. translucens cereal leaf streak-specific Xt-CLS, showing amplification using barley-seed-isolated $X$. translucens pv. translucens (from Merit 57 barley) heat-killed cells. Each template and each dilution were tested three times. Bars represent the standard error of the mean, and associated $R^{2}$ values obtained after linear regression analysis are provided. 
TABLE 4. Validation of loop-mediated isothermal amplification assays and isolation of Xanthomonas translucens with field-derived tissues ${ }^{\mathrm{y}}$

\begin{tabular}{|c|c|c|c|c|c|c|c|c|}
\hline \multirow[b]{2}{*}{ Type $^{z}$} & \multirow[b]{2}{*}{ Origin } & \multirow[b]{2}{*}{ Sym } & \multirow[b]{2}{*}{$N$} & \multicolumn{5}{|c|}{ Number of samples that amplified/number tested } \\
\hline & & & & ina-Xt & gyrB-Xt & Xt-Cerealis & Xt-Poae & Xt-CLS \\
\hline BL & Montana (2), Idaho (2) & $4 / 4$ & $4 / 4$ & $4 / 4$ & $4 / 4$ & $0 / 4$ & $0 / 4$ & $4 / 4$ \\
\hline WL & North Dakota & $1 / 1$ & $1 / 1$ & 1/1 & $1 / 1$ & $0 / 1$ & $0 / 1$ & $1 / 1$ \\
\hline BS & Colorado (5), Montana (4), North Dakota (4) & $11 / 13$ & $11 / 13$ & $11 / 13$ & $11 / 13$ & $0 / 13$ & $0 / 13$ & $11 / 13$ \\
\hline
\end{tabular}

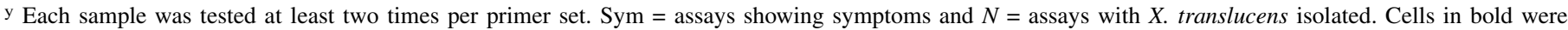
expected to amplify with the primer set in the same row. All samples were isolated using modified Wilbrink's boric acid-cephalexin semiselective medium and stored in $25 \%$ glycerol at $-80^{\circ} \mathrm{C}$.

z Sample types: $\mathrm{BL}=$ barley leaf, $\mathrm{WL}=$ wheat leaf, and $\mathrm{BS}=$ barley seed.

Xt-CLS primers. A single wheat leaf sample yielded $X$. translucens colonies on modified WBC media as well as tested positive in the ina-Xt, gyrB-Xt, and Xt-CLS assays; the isolate did not amplify with the Xt-Cerealis and Xt-Poae LAMP primers. Based on the specificities of the primers, our results show that the field isolates from barley and wheat are members of the cereal clade of $X$. translucens, which includes pathovars originally designated as undulosa, translucens, or secalis.

The turf grass sample tested amplified with the Xt-Poae primers but not with the cereal-specific primers or the Xt-Cerealis primers, consistent with the sample being infected with $X$. translucens pv. poae.

\section{DISCUSSION}

Resolving relatedness among pathovars and strains in the $X$. translucens complex has been the topic of a number of studies, each using approaches with different levels of resolution (Bragard et al. 1997; Peng et al. 2016; Rademaker et al. 2006; Vauterin et al. 2000). Our comparative genomic and phylogenetic analyses, which were based on draft genome sequences that we and others generated (Table 1) and MLSA comparisons, confirmed that the 21 tested $X$. translucens strains representing six pathovars are within the species translucens (ANI > 95\%). Phylogenetic analyses, based on MLSA using 12 housekeeping genes and EDGAR using CDS derived from the complete core genome of the draft genome sequences, allowed separation of the $X$. translucens strains into three distinct clades. One clade distinguished strains associated with cereals, particularly barley and wheat (pvs. translucens and undulosa) from those associated with noncereals (pvs. arrhenatheri, poae, and graminis). Strains representing pv. cerealis form a distinct clade, and are known to infect cereals (wheat, barley, and rye) as well as grasses (bromegrass and quack grass) (Bragard et al. 1997; Rademaker et al. 2006). The revelation of three major clades confirms previous phylogenetic groupings developed using other technologies (Bragard et al. 1997; Rademaker et al. 2006).

Based on the EDGAR analysis of homologous protein CDS (Fig. 2), we propose a core genome of 1,392 CDS for the currently representative $42 X$. translucens genomes that are publically available. This analysis shows the relative amount of all genes that are shared between and among the strains compared. By focusing on regions of the $X$. translucens genomes that overlapped among pathovars or that were unique to specific pathovars, primers specific for the species $X$. translucens and, at the pathovar level, for X. translucens pvs. poae and cerealis were identified. Selection of genomic regions found only in the cereal-infecting group allowed development of primers that distinguished cereal- from grass-infecting pathovars.

The LAMP assays described in this study allowed detection and diagnosis of $X$. translucens in plant tissues, and support distinction to cereal or grass groups that may guide regulatory officials concerned with movement of the cereal-infecting pathovars to new regions. LAMP protocols offer highly sensitive and simple tests that are adaptable to field conditions (Fischbach et al. 2015; Lang et al. 2014). Visual detection assays simplify even further the use of LAMP assays, and eliminate the need for detection equipment (Fischbach et al. 2015; Lang et al. 2014).
A major problem in developing and testing diagnostic tools for plant-pathogenic bacteria is the historical misclassification of strains or mix-ups within culture collections. Of the large number of bacterial strains tested in this study, we observed only two cases where results of LAMP assays with our primers disagreed with prior classification or suggested that strains may have been historically misnamed or the cultures mixed up. X. translucens pv. phleipratensis strain UPB441 was the only one of three pv. phleipratensis strains that amplified with the Xt-CLS primers. X. translucens $\mathrm{pv}$. graminis strain UPB437, which shares an ANIm value of $99.9 \%$ when aligned with $X$. translucens pv. graminis strain CFBP2053, was the only 1 of $13 X$. translucens pv. graminis isolates to amplify with the ina-Xt and Xt-CLS primers, even if sequence alignments indicated that the gene should not amplify. Backtracking in historical collections, or reinoculation of various hosts, would be required to resolve whether these discrepancies are due to misclassification, culture mix-ups, or genuine genetic variation in the genomes.

In conclusion, the comparative genomic analysis of the $X$. translucens complex, enabled by the draft sequencing of 15 new genomes and inclusion of previously reported genomes, confirms that all tested strains belong to the species $X$. translucens, and supports the conclusion that there are three distinct clades within the species. The release of these $X$. translucens genomes will contribute to our understanding of $X$. translucens phylogeny and will provide a platform for mining traits that contribute to pathogenic specialization and virulence. The primers developed for LAMP assays distinguish the clades as well as some pathovars within the species, and will be a valuable resource for detection, diagnosis, and monitoring of this group of important pathogens.

\section{ACKNOWLEDGMENTS}

This research was partially supported by the Colorado Wheat Administrative Committee. We thank those who supplied barley and wheat samples, including M. Burrows and L. Skoglund from Montana State University, J. Marshall from the University of Idaho, J. Menert (Annheuser-Busch), and J. Jolie (Miller-Coors); and J. Weyns (Université catholique de Louvain [UCL], Belgium), V. Van Hese (UCL), E. Duveiller (CIMMYT, Mexico), and J. Lang (Colorado State University) for technical support. V. Verdier was supported by a Marie Curie IOF Fellowship (EU Grant PIOF-GA-2009-235457). The EDGAR platform is financially supported by the German Federal Ministry for Education and Research, grant FKZ 031A533 within the de.NBI network.

\section{LITERATURE CITED}

Adhikari, T. B., Gurung, S., Hansen, J. M., and Bonman, J. M. 2012. Pathogenic and genetic diversity of Xanthomonas translucens pv. undulosa in North Dakota. Phytopathology 102:390-402.

Ash, G. J., Lang, J. M., Lindsay, R., Stodart, J., Vera Cruz, C. M., Rott, P., and Leach, J. E. 2014. Development of a genomics-based LAMP (loopmediated isothermal amplification) assay for detection of Pseudomonas fuscovaginae from rice. Plant Dis. 98:909-915.

Azad, H., and Schaad, N. W. 1988. Serological relationships among membrane proteins of strains of Xanthomonas campestris pv. translucens. Phytopathology 78:272-77.

Aziz, R. K., Bartels, D., Best, A. A., DeJongh, M., Disz, T., Edwards, R. A., Formsma, K., Gerdes, S., Glass, E. M., Kubal, M., Meyer, F., Olsen, G. J., 
Olson, R., Osterman, A. L., Overbeek, R. A., McNeil, L. K., Paarmann, D., Paczian, T., Parrello, B., Pusch, G. D., Reich, C., Stevens, R., Vassieva, O., Vonstein, V., Wilke, A., and Zagnitko, O. 2008. The RAST server: Rapid annotations using subsystems technology. BMC Genomics 9:75.

Blom, J., Albaum, S. P., Doppmeier, D., Pühler, A., Vorhölter, F., Zakrzewski, M., and Goesmann, A. 2009. EDGAR: A software framework for the comparative analysis of prokaryotic genomes. BMC Bioinf. 10:154.

Blom, J., Kreis, J., Spänig, S., Juhre, T., Bertelli, C., Ernst, C., and Goesmann, A. 2016. EDGAR 2.0: An enhanced software platform for comparative gene content analyses. Nucleic Acids Res. 44:W22-W28.

Boosalis, M. G. 1952. The epidemiology of Xanthomonas translucens (J.J. and R.) Dowson on cereals and grasses. Phytopathology 42:387-395.

Bragard, C., Singer, E., Alizadeh, A., Vauterin, L., Maraite, H., and Swings, J. 1997. Xanthomonas translucens from small grains: Diversity and phytopathological relevance. Phytopathology 87:1111-1117.

Bragard, C., Verdier, V., and Maraite, H. 1995. Genetic diversity among Xanthomonas campestris strains pathogenic for small grains. Appl. Environ. Microbiol. 61:1020-1026.

Bühlmann, A., Pothier, J. F., Rezzonico, F., Smits, T. H. M., Andreou, M., Boonham, N., Duffy, B., and Frey, J. E. 2013. Erwinia amylovora loopmediated isothermal amplification (LAMP) assay for rapid pathogen detection and on-site diagnosis of fire blight. J. Microbiol. Methods 92:332-339.

Bull, C. T., De Boer, S. H., Denny, T. P., Firrao, G., Fischer-le Saux, M., Saddler, G. S., Scortichini, M., Stead, D. E., and Takikawa, Y. 2012. Letter to the editor list of new names of plant pathogenic bacteria (2008-2010) Prepared by the International Society of Plant Pathology Committee on the Taxonomy of Plant Pathogenic Bacteria (ISPP-CTPPB). J. Plant Pathol. 94:21-27.

Dernoeden, P. H., Jackson, N., Mitkowski, N., and Kaminski, J. E. 2002. Bacterial wilt: An enigmatic annual bluegrass disease of putting greens. Golf Course Manage. January 2002:177-180.

Duveiller, E. 1990. Seed detection of Xanthomonas campestris pv. undulosa using a modification of Wilbrink's agar medium. Parasitica 40:3-17.

Duveiller, E., and Bragard, C. 1992. Comparison of immunofluorescence and two assays for detection of Xanthomonas campestris pv. undulosa in seeds of small grains. Plant Dis. 76:999-1003.

Duveiller, E., Fucikovsky, L., and Rudolph, K. 1997. The Bacterial Diseases of Wheat: Concepts and Methods of Disease Management. CIMMYT, DF, México.

Dye, D. W., Bradbury, J. F., Goto, M., Hayward, A. C., Lelliott, R. A., and Schroth, M. N. 1980. International standards for naming pathovars of phytopathogenic bacteria and a list of pathovar names and pathotypes. Rev. Plant Pathol. 59:153-168.

Edgar, R. C. 2004. MUSCLE: Multiple sequence alignment with high accuracy and high throughput. Nucleic Acids Res. 32:1792-1797.

Egli, T., and Schmidt, D. 1982. Pathogenic variation among the causal agents of bacterial wilt of forage grasses. Phytopathology 104:138-150.

Elrod, R. P., and Braun, A. C. 1947. Serological studies of the genus Xanthomonas: III. The Xanthomonas vascularum and Xanthomonas phaseoli groups; the intermediate position of Xanthomonas campestris. J. Bacteriol. 54:349-357.

Facelli, E., Taylor, C., Williams, N. M., Emmett, R. W., Sedgley, M., Joyce, C. K., and Scott, E. S. 2009. Location of Xanthomonas translucens in pistachio trees. Australas. Plant Pathol. 38:584-593.

Felsenstein, J. 1995. PHYLIP: Phylogeny Inference Package, version 3.57 c. University of Washington, Seattle.

Fischbach, J., Xander, N. C., Frohme, M., and Glökler, J. F. 2015. Shining a light on LAMP assays-A comparison of LAMP visualization methods including the novel use of berberine. Biotechniques 58:189-194.

Francis, F., Kim, J., Ramaraj, T., Farmer, A., Rush, M. C., and Ham, J. H. 2013. Comparative genomic analysis of two Burkholderia glumae strains from different geographic origins reveals a high degree of plasticity in genome structure associated with genomic islands. Mol. Genet. Genomics 288:195-203.

Frommel, M. I., and Pazos, G. 1994. Detection of Xanthomonas campestris pv. undulosa infested wheat seeds by combined liquid medium enrichment and ELISA. Plant Pathol. 43:589-596.

Gardiner, D. M., Upadhyaya, N. M., Stiller, J., Ellis, J. G., Dodds, P. N., Kazan, K., and Manners, J. M. 2014. Genomic analysis of Xanthomonas translucens pathogenic on wheat and barley reveals cross-kingdom gene transfer events and diverse protein delivery systems. PLoS One 9:e84995.

Goris, J., Konstantinidis, K. T., Klappenbach, J. A., Coenye, T., Vandamme, P., and Tiedje, J. M. 2007. DNA-DNA hybridization values and their relationship to whole-genome sequence similarities. Int. J. Syst. Evol. Microbiol. 57:81-91.

Huelsenbeck, J. P., and Ronquist, F. 2001. MRBAYES: Bayesian inference of phylogenetic trees. Bioinformatics 17:754-755.

Kumar, S., Nei, M., Dudley, J., and Tamura, K. 2008. MEGA: A biologistcentric software for evolutionary analysis of DNA and protein sequences. Brief. Bioinf. 9:299-306.
Lang, J. M., Langlois, P. A., Nguyen, M. H. R., Triplett, L. R., Purdie, L., Holton, T. A., Djikeng, A., Vera Cruz, C. M., Verdier, V., and Leach, J. E. 2014. Sensitive detection of Xanthomonas oryzae pathovars oryzae and oryzicola by loop-mediated isothermal amplification. Appl. Environ. Microbiol. 80:4519-4530.

Maes, M., Garbeva, P., and Kamoen, O. 1996. Recognition and detection in seed of the Xanthomonas pathogens that cause cereal leaf streak using rDNA spacer sequences and polymerase chain reaction. Phytopathology 86:63-69.

Majumder, D., Rajesh, T., Suting, E. G., and Debbarma, A. 2013. Detection of seed borne pathogens in wheat: Recent trends. Aust. J. Crop Sci. 7:500-507.

Marefat, A., Ophel-Keller, K., Scott, E. S., and Sedgley, M. 2006. The use of ARMS PCR in detection and identification of xanthomonads associated with pistachio dieback in Australia. Eur. J. Plant Pathol. 116:57-68.

Mitkowski, N. A., Browning, M., Basu, C., Jordan, K., and Jackson, N. 2005. Pathogenicity of Xanthomonas translucens from annual bluegrass on golf course putting greens. Plant Dis. 89:469-473.

Peng, Z., Hu, Y., Xie, J., Potnis, N., Akhunova, A., Jones, J., Liu, Z., White, F. F., and Liu, S. 2016. Long read and single molecule DNA sequencing simplifies genome assembly and TAL effector gene analysis of Xanthomonas translucens. BMC Genomics 17:21.

Pesce, C., Bolot, S., Berthelot, E., Bragard, C., Cunnac, S., Fischer-Le Saux, M., Portier, P., Arlat, M., Gagnevin, L., Jacques, M.-A., Noël, L. D., Carrère, S., and Koebnik, R. 2015a. Draft genome sequence of Xanthomonas translucens pv. graminis pathotype strain CFBP 2053. Genome Announce. 3:e01174-15.

Pesce, C., Bolot, S., Cunnac, S., Portier, P., Fischer-Le Saux, M., Jacques, M.-A., Gagnevin, L., Arlat, M., Noël, L. D., Carrère, S., Bragard, C., and Koebnik, R. 2015b. High-quality draft genome sequence of the Xanthomonas translucens pv. cerealis pathotype strain CFBP 2541. Genome Announce. 3:e01574-14.

Pothier, J. F., Pagani, M. C., Pelludat, C., Ritchie, D. F., and Duffy, B. 2011. A duplex-PCR method for species- and pathovar-level identification and detection of the quarantine plant pathogen Xanthomonas arboricola pv. pruni. J. Microbiol. Methods 86:16-24.

Rademaker, J. L. W., Norman, D. J., Forster, R. L., Louws, F. J., Schultz, M. H., and de Bruijn, F. J. 2006. Classification and identification of Xanthomonas translucens isolates, including those pathogenic to ornamental asparagus. Phytopathology 96:876-884.

Rasko, D. A., Rosovitz, M. J., Myers, G. S. A., Mongodin, E. F., Fricke, W. F., Gajer, P., Crabtree, J., Sebaihia, M., Thomson, N. R., Chaudhuri, R., Henderson, I. R., Sperandio, V., and Ravel, J. 2008. The pangenome structure of Escherichia coli: Comparative genomic analysis of E. coli commensal and pathogenic isolates. J. Bacteriol. 190:6881-6893.

Rice, P., Longden, I., and Bleasby, A. 2000. EMBOSS: The European molecular biology open software suite. Trends Genet. 16:276-277.

Schaad, N. W. 1979. Serological identification of plant pathogenic bacteria. Phytopathology 17:123-147.

Schaad, N. W., and Donaldson, R. C. 1980. Comparison of two methods for detection of Xanthomonas campestris in infected crucifer seeds. Seed Sci. Technol. 8:383-391.

Schaad, N. W., and Forster, R. L. 1985. A semiselective agar medium for isolating Xanthomonas. Phytopathology 75:260-263.

Smith, I. M. 2006. Data sheets on quarantine pests. Bull. OEPP/EPPO Bull. $36: 1-2$.

Spradlin, T. J. 1990. An improved semiselective agar medium for Xanthomonas campestris pathovar translucens. Bios 61:62-68.

Triplett, L., Koebnik, R., Verdier, V., and Leach, J. E. 2014. The genomics of Xanthomonas oryzae. Pages 127-150 in: Genomics of Plant-Associated Bacteria. D. C. Gross, A. Lichens-Park, and C. Kole, eds. Springer, Berlin Heidelberg.

Triplett, L. R., Hamilton, J. P., Buell, C. R., Tisserat, N.A., Verdier, V., Zink, F., and Leach, J. E. 2011. Genomic analysis of Xanthomonas oryzae isolates from rice grown in the United States reveals substantial divergence from known X. oryzae pathovars. Appl. Environ. Microbiol. 77:3930-3937.

Tubajika, K. M., Tillman, B. L., Russin, J. S., Clark, C. A., and Harrison, S. A. 1998. Relationship between flag leaf symptoms caused by Xanthomonas translucens pv. translucens and subsequent seed transmission in wheat. Plant Dis. 82:1341-1344.

Vauterin, L., Rademaker, J., and Swings, J. 2000. Synopsis on the taxonomy of the genus Xanthomonas. Phytopathology 90:677-82.

Vauterin, L., and Swings, J. 1997. Are classification and phytopathological diversity compatible in Xanthomonas? J. Ind. Microbiol. Biotechnol. 19:77-82.

Vauterin, L., Swings, J., Kersters, K., Gillis, M., Mew, T. W., Schroth, M. N., Palleroni, N. J., Hildebrand, D. C., Stead, D. E., Civerolo, E. L., Hayward, A. C., Maraite, H., Stall, R. E., Vidaver, A. K., and Bradbury, J. F. 1990. Towards an improved taxonomy of Xanthomonas. Int. J. Syst. Evol. Bacteriol. 40:312-316.

Wichmann, F., Vorhölter, F., Hersemann, L., Widmer, F., Blom, J., Niehaus, K., Reinhard, S., Conradin, C., and Kölliker, R. 2013. The noncanonical type III secretion system of Xanthomonas translucens pv. graminis is essential for forage grass infection. Mol. Plant Pathol. 14:576-588. 